Радослава Трнавац

Универзитет у Београду

Филолошки факултет

Катедра за славистику

radoslava.trnavac@fil.bg.ac.rs
УДК 811.161.1'367.623'37: 811.163.41'367.623'37

https://doi.org/10.18485/slavistika.2020.24.2.6

оригинални научни рад примљено 11.02.2020.

прихваћено за штампу 18.09.2020.

\title{
СЕМАНТИЧКА АНАЛИЗА НЕКОЛИКО ПРИДЕВА СА АФЕКТИВНИМ И ИСКУСТВЕНИМ ЗНАЧЕЊЕМ У СРПСКОМ И РУСКОМ ЈЕЗИКУ*
}

Рад се бави семантичком анализом дванаест придева са афективним и искуственим значењем у српском и руском језику уз помоћ природног семантичког метајезика (Goddard and Wierzbicka 2014; Goddard et al. 2019). Дистинкција између наведене две групе придева се, између осталог, врши на основу броја присутних психолошких димензија које карактеришу емотивни простор (Fontaine et al. 2013).

Кључне речи: природни семантички метајезик, придеви са афективним и искуственим значењем, димензије емотивног простора, српски језик, руски језик.

The objective of this paper is to demonstrate the semantic analysis of twelve adjectives with affective and experiential meaning in Serbian and in Russian based on the Natural Semantic Metalanguage (Goddard and Wierzbicka 2014; Goddard et al. 2019). We suggest that a basic distinction between the two above-mentioned groups of adjectives can be established thanks to the presence of different number of psychological dimensions that characterize emotional space (Fontaine et al. 2013).

Keywords: Natural Semantic Metalanguage, adjectives with affective and experiential meaning, dimensions of emotional space, Serbian, Russian.

\section{1.Увод}

У овом раду ћемо се бавити лексичко-семантичком анализом неколико евалуативних придева са афективним и искуственим значењем у српском и руском језику. Евалуативни придеви представљају интересантну област за проучавање, посебно због развоја сентимент анализе и ,афективног рачунања“ у оквиру рачунарске лингвистике у последњих двадесетак година (Picard 1997; Pang and Lee 2008). Придеви које ћемо разматрати припадају подсистему за естетску оцену, који представља део модела оцене (Martin and White 2005). Овај подсистем обухвата придеве који указују на естетски квалитет објеката или природних феномена (изванредан, елегантан, иновативан). Модел оцене се веома често употребљава у циљу креирања лексикона субјективне лексике и ради класификације дате лексике у оквиру три подсистема - афекта, суда и естетске евалуације. У нашем претходном раду (Goddard et al. 2019) предложили смо класификацију евалуативних придева на енглеском језику у пет група за коју мислимо да би могла да има универзалнији карактер и да се односи на већи број језика. У овом раду

* Овај рад је написан у оквиру пројекта „Опис и стандардизација савременог српског језика“ (178021), који финансира Министарство просвете, науке и технолошког развоја Републике Србије. 
ћемо анализирати на основу природног семантичког метајезика (Wierzbicka 1972; Wierzbicka 1999; Goddard and Wierzbicka 2014) прве две групе придева из наведене класификације који се непосредно фокусирају на афект и на искуствени доживљај говорника. Анализа ће обухватити дванаест придева на српском и на руском језику (по шест из сваког језика), а теоријска новина овог рада представља предлог дистинкције која се може направити у оквиру самих експликација за две наведене групе придева. Као идеја за наведену дистинкцију су нам послужила истраживања спроведена у швајцарском институту за афективне науке где група научника у анализи афективног простора у оквиру психологије и когнитивних наука користи четири димензије: валентност, потентност, активацију и новину (Fontaine et al. 2013; Gillioz et al. 2016). У избору примера придева које ћемо анализирати су нам послужили поједини придеви наведени у списковима у монографији Драгићевић (2001) за српски језик, а за руски језик нам је послужила монографија Шаховског (2008). Једини критеријум за избор наведених придева из поменутих радова је био да припадају афективном и искуственом простору. Због ограниченог простора у раду, одлучили смо се на анализу релативно малог броја примера. По свом значењу, анализирани придеви су сложени и могу бити разложени уз помоћ семантички „базичних“ јединица, тзв. „примитива“ у оквиру лексико-семантичке анализе која се заснива на природном семантичком метајезику (Goddard and Wierzbicka 2014).

У даљем раду ћемо материјал излагати на следећи начин. У наредном поглављу ћемо презентовати основне поставке модела оцене, природног семантичког језика и димензионалног приступа изучавању емоција у психологији. У поглављу 3 ћемо кратко описати класификацију евалуативних придева предложену у раду Годарда и др. (2019). У поглављу 4 ћемо понудити семантичке експликације за шест придева на српском и за шест придева на руском језику. Поглавље 5 представља закључак овог рада.

\section{2. Модел оцене, природни семантички метајезик и димензионални при- ступ изучавању емоција}

У овом поглављу ћемо презентовати основне теоријске поставке на основу којих се касније врши класификација евалуативних придева са афективном и искуственом компонентом. У првом делу ћемо дати кратки приказ модела оцене Мартина и Вајта (2005) који представља до сада најдетаљнији приступ феномену евалуације, а затим ћемо навести ком делу овог модела припадају наведени придеви. Потом ћемо описати основне поставке семантичке анализе која се врши на основу природног семантичког метајезика (Wierzbicka 1972; Wierzbicka 1999; Goddard and Wierzbicka 2014), да би на крају поглавља укратко приказали димензионални приступ узучавању емоција Фонтејна и др. (Fontaine et al. 2013) који нам је послужио као параметар за разграничење две врсте придева о којима је реч у датом раду.

\section{1 Пројекција евалуативних придева у оквиру модела оцене}

Модел оцене припада тзв. системско-функционалном правцу у лингвистици који је иницирао Халидеј (Halliday 1985; Halliday and Matthiessen 2014) и који 
су такође развијали Џим Мартин, Питер Вајт и колеге (Martin, 2000; Martin and White 2005; White 2012; Martin, 2014). Мартин (2000) карактерише оцену као скуп вербалних средстава који се користе да би се изражавале емоције, судови и вредности заједно са средствима за амплификацију и за изражавање ангажмана говорника. Овај модел се реализује кроз придеве као централну врсту речи, али може бити реализован и кроз именице, глаголе, прилоге и друге врсте речи, као и кроз синтагме и конструкције. Централни аспект модела оцене представљају три подсистема - подсистем за изражавање афекта, подсистем за изражавање суда и подсистем за изражавање естетске евалуације. Подсистем за изражавање афекта обухвата лексику којом се карактерише емотивни став говорника или нечија туђа реакција (срећа, страх). Подсистем за изражавање суда о нечему симболизује евалуацију морала неке особе (лажан, храбар). Подсистем за изражавање естетске евалуације обухвата лексику која указује на естетски квалитет објеката (изванредан, елегантан). Осим централне теме која је представљена наведеним подсистемима, Мартин и Вајт (2005) сматрају да постоје још два периферна подсистема који играју улогу у изражавању мишљења. Подсистем градације је одговоран за говорникову способност да интензивира или ослаби снагу сопственог мишљења, те има силу или фокус као своје категорије. Сила подразумева интензивирање или слабљење речи чије се значење може окарактерисати кроз меру, док фокус репрезентује начин на који говорници могу да изоштре или омекшају речи које изражавају објекат који има значење немерљиве количине. Последњи подсистем је ангажман који представља скуп лингвистичких опција које дозвољавају да појединац преноси степен своје привржености изнесеном мишљењу.

Евалуативни придеви са афективним и искуственим значењем у оквиру приказаног система припадају подсистему естетске евалуације. У оквиру подсистема за естетску евалуацију постоји детаљнија класификација елемената. Група придева која у себи садржи афективну, десидеративну или квалитативну компоненту значења се у даљој класификацији групише у оквиру категорије реакције (Martin and White 2005: 55). Придеви у овој категорији одговарају на следећа питања: „Да ли ме је нешто привукло“? „Да ли нешто желим?“ или „Да ли ми се нешто свидело?“ Следећа група придева припада категорији елемената за изражавање састава или композиције нечега, а њихово значење исказује перцептивно запажање говорника у вези са неким субјектом или објектом. Значење ових придева одговара на питање „Колико се делови неког ентитета уклапају у целину?““ Последња категорија у оквиру подсистема за изражавање естетске евалуације је категорија процењивања која укључује придеве чије значење изражава мишљење говорника или писца да су анализиране појаве или објекти корисни за нешто. У наредној табели ћемо навести примере појединих врста придева који припадају подсистему за естетску евалуацију и који су преведени из књиге Мартина и Вајта (2005: 56): 
Прилог 1

\begin{tabular}{|c|c|}
\hline $\begin{array}{c}\text { Реакција „Да ли ме је нешто привукло?“ } \\
\text { (утицај) }\end{array}$ & $\begin{array}{l}\text { узбудлив, дирљив, } \\
\text { интензиван }\end{array}$ \\
\hline $\begin{array}{c}\text { Реакција „, Да ли ми се нешто свидело?“ } \\
\text { (квалитет) }\end{array}$ & добар, леп, сјајан \\
\hline $\begin{array}{c}\text { Композиција „Да ли се ствари уклапају“‘? } \\
\text { (баланс) }\end{array}$ & $\begin{array}{c}\text { хармоничан, уједначен, } \\
\text { логичан }\end{array}$ \\
\hline $\begin{array}{c}\text { Композиција „Да ли је нешто тешко пратити?“ } \\
\text { (комплексност) }\end{array}$ & $\begin{array}{c}\text { једноставан, прециизан, } \\
\text { елегантан }\end{array}$ \\
\hline Процењивање „Да ли је нешто вредело“? & $\begin{array}{c}\text { дубок, оригиналан, } \\
\text { иновативан }\end{array}$ \\
\hline
\end{tabular}

Табела 1: Примери придева у оквиру подсистема за естетску евалуацију

Као што је то већ наведено у раду Годарда и др. (2019), придеви са афективним и искуственим значењем се поклапају са првим двема категоријама из табеле подсистема за естетску евалуацију Мартина и Вајта (2005) - са придевима који изражавају реакцију, а који у себи садрже значење којим се исказује утицај (на некога или нешто) или значење за изражавање квалитета (некога или нечега).

Пошто смо окарактерисали простор који заузимају наши придеви у оквиру модела оцене, прећи ћемо на карактеризацију семантичке анализе која ће бити примењена у овом раду.

\section{2 Семантичка анализа помоһу природног семантичког метајезика}

Природни семантички метајезик се током свог развоја као научни правац више пута бавио семантичком анализом речи које изражавају емоције (Wierzbicka 1999; Harkins and Wierzbicka 2001; Goddard and Ye 2016). У својој семантичкој анализи пропоненти овог правца су користили семантичке обрасце, односно експликације у оквиру различитих домена лексикона, укључујући глаголе (Goddard and Wierzbicka 2014), именице (Ye 2017) и придеве (Goddard et al. 2019). Познато је да је приступ природног семантичког метајезика припада когнитивном правцу карактерисања значења и да се почетак развоја овог правца може испратити од појаве монографије Ане Вјежбицке из 1972. године. Теорија природног семантичког метајезика покушава да редукује семантику целог лексикона на ограничен број семантичких примитива (базичних концепата), којих има у садашњој теорији шездесет и пет ${ }^{1}$. Поборници ове теорије тврде да примитиви представљају универзалне концепте и да имају своје преводне еквиваленте у сваком језику, као и да примитиви током семантичке ана-

\footnotetext{
${ }^{1}$ Погледати табелу са 65 примитива у оквиру природног семантичког метајезика у раду Годарда и др. (2019: 330) 
лизе не могу бити „разложени“ на једноставније концепте, већ да представљају базу за дефинисање сложенијих од њих концепата. Природни семантички метајезик користи технику парафразирања уз присуство првог лица једнине ради презентације субјективног значења. Методологија примене семантичке анализе у оквиру природног семантичког метајезика је погодна за анализу свих лексема које репрезентују сложеније концепте од примитива јер се ова анализа врши комбиновањем самих примитива. Све експликације добијене комбиновањем примитива треба на интуитивном нивоу да буду доступне говорницима одређеног језика на којем се експликација врши. Истраживања у оквиру датог правца се детаљно баве односом језика и когниције, као и језика и култуpe, укључујући области као што су лексичка и граматичка семантика, прагматика и интеркултурална комуникација.

Да бисмо представили облик и структуру семантичких експликација у оквиру овог лингвистичког правца, презентоваћемо експликацију за придев феноменалан, који према теорији природног семантичког метајезика предстаља сложени концепт јер се не налази у списку примитива и чије значење се приликом семантичке анализе може објаснити уз помоћ базичних концепата/примитива:

\section{Прилог 2 \\ Феноменалан (одмор):}

Образац А, нпр. сјајан роман, предиван филм

\begin{tabular}{|c|c|}
\hline Ја мислим о томе као ово: & Мисао изражена у првом лицу \\
\hline $\begin{array}{c}\text { „Ово Х је веома добро } \\
\text { Ја нисам знао пре да Х (овакве ства- } \\
\text { ри) могу да буду овакве“ }\end{array}$ & Мисаони процес \\
\hline $\begin{array}{c}\text { Када мислим тако, } \\
\text { осећам нешто веома добро } \\
\text { због тога }\end{array}$ & Осећање \\
\hline
\end{tabular}

Експликација представља одређени семантички образац који се састоји од четири дела који се именују као мисао, садржина мисли, осећање и прототипичност (видети Goddard 2014; Goddard et al. 2019). Ови делови укључују прототипску мисао говорника, њену садржину и осећање (пријатно или непријатно, односно добро или лоше у терминологији природног семантичког метајезика), које је обично изазвано одређеном врстом мисли.

Након илустрације кратке суштине теорије природног семантичког језика и његове примене на језик емоција осврнућемо се на димензионални принцип описа емоција у психологији. 


\section{3 Димензионални приступ изучавању емоција}

Димензионални приступ изучавању емоција у психологији предвиђа да су емоције одређене малим бројем фундаменталних димензија (Fontaine et al. 2013: 32). Историјски, већ је Аристотел оцењивао емоционално искуство од крајње позитивног до крајње негативног. У 17. веку Спиноза је класификовао емоције према јачини, као и према дужини трајања. Психологија је такође крајем 19. и почетком 20. века поставила основе за димензионални приступ емоцијама. Вилијем Вунд је поделио емоције на пријатне-непријатне, узбудљиве-мирне и стресне-опуштајуће. Ми у овом раду преузимамо четвородимензионални приступ класификацији емоција који су креирали Фортејн и др. (2013), а у оквиру кога се издвајају следеће димензије: валентност (позитивне и негативне емоције), потентност (јачина; на пример бес је супротстављен меланхолији према овој димензији), активација (бес и љутюа су овде супротстављени емоцији туге; емоције које су високо рангиране на датој скали доводе до активације личности да предузме нешто) и новина (карактерише оцену субјекта у смислу неочекиваности појаве одређене емоције).

У оквиру лингвистичке анализе дванаест придева наша хипотеза би била да су прве две димензије битне за образац евалуативних придева који припадају категорији А, док је барем једна од друге две димензије карактеристична за образац који се примењује на придеве категорије В1 и В2 (поред валентности и факултативно потентности).

\section{3. Класификација евалуативних придева према Годарду и др. (2019)}

У раду Годарда и др. (2019) је издвојено пет образаца који презентују домен евалуативних придева. За детаљнији преглед класификације евалуативних придева и критеријума на основу којих је она направљена, упућујемо читаоца на сам рад. Сматрамо да је самом класификацијом направљен допринос проучавању евалуативне лексике у области лексичке семантике јер је по први пут извршена класификација евалуативних придева у поменутој области.

Приликом истраживачког дела, аутори горе поменутог рада су издвојили четрдесетак најфреквентних евалуативних придева на енглеском језику који се налазе у саставу дигиталних корпуса WordBanks Online [http://wordbanks. harpercollins.co.uk], Корпуса савременог енглеског језика у Северној Америчи (COCA, Davis, 2008) и Корпуса рещензија Сајмон Фрејзер универзитета (Taboada $2008)$ и анализирали су њихова значења у саставу колокација. Сваки придев је био анализиран у контексту од 200 примера. Користећи методе интроспекције (ослањања на интуицију говорника језика) и „експериментисања кроз покушаје и погрешке“" (trial-and-error experimentation method), које се увек користе приликом примене модела природног семантичког метајезика, аутори рада су груписали пет основних образаца којим би била дефинисана семантика евалуативних придева на основу издвојених значења за наведених четрдесетак придева. Аутори су такође креирали прототипове експликација за пет образаца, као и саме експликације за сваки од анализираних придева. Напоменућемо у овом делу рада чињеницу која је добро позната свим лингвистима који се баве семантичким анализом користећи метод природног семантичког метајезика. Свака 
експликација је субјективне природе. Два аналитичара не могу да произведу истоветну експликацију дефинишући један исти појам. Критеријум који јесте битан при оцени сваке експликације је колико је она интуитивно прихватљива за говорника једног језика.

У овом раду ћемо само кратко представити свих пет образаца евалуативних придева, а затим ћемо се фокусирати на анализу оних који припадају обрасцима А и В јер они постоје и у српском и у руском језику2 ${ }^{2}$ Методологија анализе у нашем раду је, као и класификација евалуативних придева, преузета из рада Годарда и др. (2019). Након избора 12 придева на српском и на руском језику који, по нашем мишљењу, одговарају обрасцима А и В, експликације ових придева смо формирали на основу постојећих прототипова експликација из рада Годарда и др. (2019), додајући тим експликацијама засебне компоненте које издвајају сваки од анализираних придева. У току процеса настанка експликација консултовали смо значења анализираних придева у речницима савременог српског и руског језика.

У даљем тексту ћемо представити прототипове експликација за свих пет образаца, онако како су презентовани у раду Годарда и др. (2019), а затим и у раду Трнавац и Табоаде (2019), а потом ћемо се у следећем одељку детаљније позабавити анализом конкретних придева који припадају обрасцима А и В.

Сви придеви који припадају обрасцу А започињу компонентном која указује на мисаони процес: „Ја мислим о томе X на овај начин...“. Затим следи модел мисли, након кога долази до изражавања појачане евалуације типа „Ово X је веома добро“, а потом се експликација за сваки посебан придев наставља са додатним једним или два реда. Посебност изражавања евалуације сваког анализираног придева долази управо од компоненти тих додатних редова који су другачији за сваки засебни придев. Образац се завршава компонентом која указује да дати модел размишљања води ка томе да говорник осећа нешто „веома добро“ (или: „веома лоше“) (Goddard et al. 2019: 317). Придеви који припадају овом обрасцу се сматрају „веома субјективним“ јер у саставу својих експликација увек садрже мисаону компоненту, као и компоненту емоције изазване код говорника ситуацијом у којој је употребљен дати придев. Именице покрај анализираних придева су наведене да би читаоцима било лакше да формирају представу о контексту у коме се употребљава одређени евалуативни придев.

${ }^{2}$ У раду Годарда и др. (2019) се не тврди да је понуђена класификација евалуативних придева нити универзалне, нити коначне природе, али, по нашем мишљењу, прототипови експликација евалуативних придева са семантиком афекта и искуства на енглеском језику могу да се успешно искористе приликом семантичке анализе придева са датом семантиком на српском и на руском језику. 
Прилог 3

Образац А, нпр. сјајан роман, предиван филм

\begin{tabular}{|c|c|}
\hline Ја мислим о овоме Х овако: & Мисао изражена у првом лицу \\
\hline “ & Мисаони процес \\
\hline $\begin{array}{c}\text { Када мислим о томе, } \\
\text { ја осећам нешто } \\
\text { веома добро/лоше због тога }\end{array}$ & Ocећање \\
\hline
\end{tabular}

Придеви који припадају обрасцима В1 и В2 указују на семантику „искуства“ говорника о стварима које се оцењују. Они, заправо, описују искусто из реалног контекста које говорник доживљава док се радња одиграва, као, на пример, у изразима забавна игра или одвратан призор. Често се ова врста придева повезује са дуративним контекстима, односно ситуацијама где би искуство нечега могло да траје неко време и где би мисао о том искуству могла да се перидично понавља. Образац В2 има додатну компоненту у односу на В1 јер поседује елемент који изражава одређену телесну реакцију услед искуства кроз које говорник пролази (Goddard et al. 2019: 323-324). Придеви који припадају обрасцу В се сматрају мање субјективним од придева који припадају обрасцу А с обзиром на то да емоција коју говорник осећа приликом пролажења кроз дато искуство је факултативне природе („Када овај неко мисли овако, он/она могу да осећају нешто“).

\section{Прилог 4}

Образац В1, забавна књига, интересантан модел

\begin{tabular}{|c|c|}
\hline $\begin{array}{c}\text { Током овог времена } \\
\text { (када се неке ствари дешавају некоме) }\end{array}$ & Дуративни фрејм \\
\hline $\begin{array}{c}\text { Овај неко може да мисли овако } \\
\text { много пута: }\end{array}$ & Потенцијална мисао \\
\hline “ & Мисао \\
\hline $\begin{array}{c}\text { Када овај неко мисли овако, } \\
\text { он/она могу да осећају нешто ((веома) } \\
\text { добро/лоше) због тога }\end{array}$ & Осећање \\
\hline
\end{tabular}




\section{Прилог 5}

Образац В2, узбудљива драма, фасиинантна слика

\begin{tabular}{|c|c|}
\hline $\begin{array}{c}\text { Током овог времена } \\
\text { (када се неке ствари дешавају некоме) }\end{array}$ & Дуративни фрејм \\
\hline Овај неко може да мисли овако \\
много пута: & Потенцијална мисао \\
\hline “ & Мисао \\
\hline $\begin{array}{c}\text { Када овај неко мисли овако, } \\
\text { он/она могу (или: не морају) } \\
\text { да осећају нешто ((веома) добро/лоше) } \\
\text { због тога }\end{array}$ & Осећање \\
\hline У исто време он/она могу да осећају \\
нешто у телу због тога \\
и/или: у исто време нешто може \\
да се деси у његовом/њеном телу \\
због тога
\end{tabular}

Следећа група придева се фокусира у својој семантици и доле наведеној експликацији на континуирани ефекат који има неко искуство на говорника након што је завршено са датим искуством (Goddard et al. 2019: 326).

\section{Прилог 6}

Образац С, незабораван догађај, инспиративан рад

\begin{tabular}{|c|c|}
\hline $\begin{array}{c}\text { Када неко ради нешто неко време, } \\
\text { нешто му се дешава због тога }\end{array}$ & Ефекат \\
\hline Нешто се дешава овоме \\
некоме због тога \\
Због тога, неко време после тога, \\
то је овако: \\
“ \\
Људи могу о овоме мислити овако: \\
„то је добро/лоше“
\end{tabular}


У оквиру обрасца D се налазе придеви са когнитивном оценом нечега обично без укључивања било какве емоције. Закључак о некој ствари чију семантику носе дати придеви може се донети тек након тога што субјекат проучи ствар коју карактерише.

Прилог 7

Образац D, сложени механизам, импресивна методологија

\begin{tabular}{|c|c|}
\hline Ако неко зна како је ово X & Информација \\
\hline $\begin{array}{c}\text { он/она може да мисли о овоме } \\
\text { (или: о некоме) овако: }\end{array}$ & Потенцијална мисао \\
\hline “ & Мисао \\
\hline
\end{tabular}

У следећем одељку, имајући у виду наведене прототипове експликација, бавићемо се детаљније семантичком анализом одабраних придева који припадају категоријама А и В.

\section{4. Семантичка анализа групе придева}

У овом делу рада ћемо представити лексичко-семантичку анализу шест придева на српском и шест придева на руском језику који припадају обрасцима A, B1 и В2 категорије. Одабрали смо поменути број придева због ограниченог простора у раду, а у исто време сматрамо да тај број може успешно да илуструје потенцијалну семантичку анализу евалуативних придева. Ради компарације значења, за сваки придев ћемо навести речничку дефиницију, а затим и нашу експликацију значења. Током креирања наших експликација контекст за дате лексеме смо налазили у речницима, као и на интернет претраживачу гугл. У закључку овог рада ћемо понудити објашњење о предностима наше семантичке анализе у односу на дефиниције значења из речника.

У оквиру групе придева категорије А анализираћемо придеве феноменалан, грозан, классный и ужасный. Према дефиницији наведеној у раду Годарда и др. (2019: 317), придеви у овој категорији често припадају предикативима који се употребљавају у оквиру конуструкција типа Осећам се сјајно. Исто тако, они се могу користити и у самосталним експресивним изразима типа Сјајно! С обзиром да у својој семантици садрже компоненту осећања, они су блиски категорији афекта према класификацији евалуативне лексике Мартина и Вајта (2005).

Придев феноменалан према 1. дефиницији Речника српскога језика Матице српске (Вујанић и др., 2011) се објашњава синонимичним изразима изузетан, извранредан, а експликацију за ово значење ћемо поновити из претходног поглавља. Дати придев у том значењу можемо употребити са следећим именицама: феноменално памћење, феноменална издржљивост, феноменалан човек, феноменалан песник. Он је у овом раду дефинисан уз помоћ природног семантичког метајезика у табели 2. 
Као што се види из дате експликације, када говорник употреби придев $\phi е-$ номеналан, он има у виду ситуацију у којој доживљава неку појаву коју карактерише овим придевом (нпр. памћење) као нешто што до сада није имао прилике да искуси. Говорник је толико одушевљен датом појавом да би желео што више о њој да каже, али у исто време не налази праве речи да опише дату појаву. Као што се види из ове експликације, придев феноменалан садржи емоцију која може бити карактерисана двема димензијама - валентношћу и потентношћу. То значи да је емоција коју у својој евалуативној семантици носи придев феноменалан окарактерисана позитивном вредношћу и јачином (говорник осећа нешто веома добро). Експликација у себи садржи покушај активације говорника да нешто каже, али се она одиграва безуспешно (,Желим да кажем нешто више о томе, у исто време не знам шта могу да кажем ").

Следећи придев за који предлажемо експликацију на основу природног семантичког метајезика је придев грозан. За њега Речник српског језика Матице српске издваја следећа два значења:

1. Онај који изазива грозу; језив, страшан, ужасан: -привиђење, -призор, -казна, - клетва, -злочин. 2. врло лош, опак, суров, ужасан: -жена, -човек.

Ми ћемо у оквиру наше експликације обухватити оба значење датог придева.

Прилог 8

грозан X, грозна слика, грозан призор

\begin{tabular}{|c|c|}
\hline Ја мислим о овоме Х овако: & Мисао изражена у првом лицу \\
\hline „Ово Х је веома лоше & Мисаони процес \\
Нешто веома лоше може & \\
да се деси некоме због тога “ & Осећање \\
\hline Када мислим овако, \\
ја осећам нешто веома лоше због тога
\end{tabular}

Експликација овог придева рефлектује страх говорника у односу на манифестацију појаве која је симболизована именицом. Као и претходна експликација, и ова садржи емоцију коју карактеришу две димензије - валентност и потентност („Када мислим овако, ја осећам нешто веома лоше због тога“).

Руски придеви классный и ужасный имају слична значења попут претходних придева на српском језику. Придев классный као једно од значења има оно које указује на нешто што је високог квалитета према дефиницији из речника руског језика Ожегова (1990), као у реченици типа У тебя классный рюкзак! (,Твој ранац је фантастичан“). 


\section{Прилог 9}

Классный Х, классный фильм, классные ботинки

\begin{tabular}{|c|c|}
\hline Ја мислим о овоме Х овако: & Мисао изражена у првом лицу \\
\hline „Ово Х је веома добро \\
Људи могу да мисле ово: \\
овако нешто не може бити.“
\end{tabular}

Врло често предност природног семантичког метајезика у односу на речничке дефиниције је у томе што се њиме могу исказати дискретне разлике у значењима код лексема блиских по својој семантици. С друге стране, већина речника дефинише значења неке речи синонимичним лексемама (на пример, погледати у претходном тексту дефиницију значења лексеме грозан из Речника сриског језика Матице српске).

Придеви феноменалан и классный су веома блиски по свом значењу. У оквиру наше семантичке анализе разлика у њиховим значењима би била исказана у сегменту мисаоног процеса говорника. Док придев феноменалан садржи у себи мисао: „Ја нисам знао пре да X (=такве ствари) могу бити овакве“, придев классный се од њега разликује захваљујући следећој компоненти: „Људи могу да мисле ово: овако нешто не може бити.“ Дакле, придев феноменалан указује на висок квалитет нечега који је потпуно нов за говорника, док квалитет исказан придевом классный указује на особину нечега што би на тај начин било окарактерисано од стране широког спектра људи. Придев классный као и придев феноменалан такође садржи две димензије афекта по којима се поклапају - валентност и потентност („Када мислим о томе, ја осећам нешто веома добро због тога“).

Придев ужасный према речнику руског језика Ожегова (1990) у једном се од својих значења дефинише као очень плохой, што, по нашем мишљењу, недовољно прецизно семантички одређује дату лексему. Ми смо креирали следећу експликацију за ово значење:

\section{Прилог 10}

Ужасный Х, ужасная ошибка, ужасная деталь

\begin{tabular}{|c|c|}
\hline Ја мислим о овоме Х овако: & Мисао изражена у првом лицу \\
\hline $\begin{array}{c}\text { „Ово Х је веома лоше } \\
\text { Нешто веома лоше може да се деси } \\
\text { људима због тога. “ }\end{array}$ & Мисаони процес \\
\hline $\begin{array}{c}\text { Када мислим овако, } \\
\text { ја осећам нешто веома лоше због тога }\end{array}$ & Осећање \\
\hline
\end{tabular}


Ако упоредимо разлику између придева грозан и придева ужасный , који су блиски по значењу у два језика, запазићемо да се они такође могу разликовати међу собом по компоненти која је део мисаоног процеса говорника. Док придев грозан садржи компоненту „, Нешто веома лоше може да се деси некоме због тога“, придев ужасный има за нијансу другачију компоненту у оквиру мисаоног процеса: „Нешто веома лоше може да се деси људима због тога“. У оквиру експликације за придев ужасный акцентује се да се негативне последице на које придев указује могу одражавати и на већу количину људи, те придев понекада носи мање изражену личну компоненту од придева грозан. Тако да, на пример, придев ужаснылй се може чешће наћи у контексту метеоролошких непогода (ужасные последствия урагана) од придева грозан у српском језику, док се придев грозан обично налази у више персонализованим контекстима (изгледати грозно; имати грозан плик) $)^{3}$. У описаном значењу придева ужасный, као што је то случај са претходним придевима, приметно је присуство две димензије афекта, а то су валентност, односно маркирање негативних емоција, као и потентност, односно означавање јачине датих емоција (Када мислим о томе, ја осећам нешто веома лоше због тога).

Придеви који могу бити класификовани у оквиру образаца В1 и В2 указују на говорниково „искуство“ у вези са стварима које се оцењују. Ови придеви најчешће описују искуство које се одвија у тренутку када субјекат обавља неку активност (Goddard et al. 2019: 320), типа узбудљива игра, интересантна храна, забаван филм, итд. Многи од придева у датој категорији су дуративни јер искуство које се њима описује траје неко време. У дуративним контекстима, искуствена евалуација може бити исказана у виду мисли која се може репетитивно понављати у оквиру одређеног времена трајања радње, уз појаву одређене емоције. Из овог разлога, дати придеви укључују следеће компоненте: „током овог времена, овај неко може да мисли ово много пута“, што је пропраћено компонентом „када овај неко мисли овако, он/она може да осећа нешто добро/лоше због тога“. На пример, придев очаравајући 4 би могао бити описан следећим сценаријем:

\footnotetext{
${ }^{3}$ Нијанса о којој говоримо, а која се тиче разлике у значењу ова два придева, заиста је мала јер у великом броју случајева и један и други придев се могу наћи у оба типа контекста (персонализованом или деперсонализованом контексту). То је такође сигнализирано експликацијом за придев грозан - неко у датој експликацији може представљати како појединца, тако и множину, односно људе.

${ }^{4}$ У оквиру Речника српскога језика Матице српске (2011) значење је понуђено за глагол очарати који се објашњава синонимичним изразима опчинити, омађијати, одушевити, усхитити. Придеви у оквиру категорије В1 имају често глаголско порекло (Goddard et al. 2019: 320).
} 


\section{Прилог 11}

очаравајући Х, очаравајући дом, очаравајућа слика

\begin{tabular}{|c|c|}
\hline $\begin{array}{c}\text { Током овог времена } \\
\text { (када се неке ствари дешавају некоме) }\end{array}$ & Дуративни фрејм \\
\hline $\begin{array}{c}\text { Овај неко може да мисли } \\
\text { овако много пута: }\end{array}$ & Потенцијална мисао \\
\hline $\begin{array}{c}\text { „тео бих да знам више о томе, } \\
\text { пуно бих хтео.“ }\end{array}$ & Мисао \\
\hline $\begin{array}{c}\text { Када овај неко мисли овако, } \\
\text { он/она могу да осећају нешто веома } \\
\text { добро због тога }\end{array}$ & Oсећање \\
\hline
\end{tabular}

Као што се види из датог сценарија, поред димензија валентности и потентности (могу да осећају нешто веома добро због тога) које су обухваћене придевима А категорије, дати сценарио укључује димензију активације субјекта што условљава да субјекат предузме неке активности (,Хтео бих да знам више о томе, пуно бих хтео“). Такође, значење датог придева подразумева и димензију новине која није постојала док се радња није почела одвијати. Слично се може рећи и о придеву неодољив који се у речнику Матице српске дефинише на следећи начин: неодољив, -а, -о коме, чему се не може одолети, супротставити; веома привлачан.

\section{Прилог 12}

неодољив X, неодољива прича, неодољива дестинащчија

\begin{tabular}{|c|c|}
\hline $\begin{array}{c}\text { Током овог времена } \\
\text { (када се неке ствари дешавају некоме) }\end{array}$ & Дуративни фрејм \\
\hline $\begin{array}{c}\text { Овај неко може да мисли } \\
\text { овако много пута: }\end{array}$ & Потенцијална мисао \\
\hline $\begin{array}{c}\text { „Нешто се дешава сада. } \\
\text { Хтео бих да знам шта ће се десити } \\
\text { након тога. } \\
\text { Ја морам да знам то.“ }\end{array}$ & Мисао \\
\hline $\begin{array}{c}\text { Када овај неко мисли овако, } \\
\text { он/она може да осећа нешто због тога }\end{array}$ & Осећање \\
што не осећају људи у многим другим тренуцима & \\
\hline
\end{tabular}

Придев неодољив у свом значењу садржи димензије валентности, активације (,Хтео бих да знам шта ће се десити након тога. Ја морам да знам то“), потенције 
која у датом случају изражава велику количину присутне емоције („он/она могу да осећају нешто због тога што не осећају људи у многим другим тренуцима“), али и новине јер дата емоција није постојала пре саме радње. Према нашој семантичкој анализи, придеви очаравајући и неодољив, који су релативно блиски по свом значењу, разликују се у својој семантици по компоненти која се односи на мисаони процес говорника: „Хтео бих да знам више о томе, пуно бих хтео“ (очаравајући) и „Нешто се дешава сада. Хтео бих да знам шта ће се десити након тога. Ја морам да знам то“ (неодољив). Такође се разликују и по компоненти потенције с обзиром на то да је она присутнија у јачој мери код придева неодољив.

Придеви у руском језику трогательный и скучный, као и претходна група на српском језику у оквиру категорије В1, рефлектују унутар својих експликација барем три од постојеће четири психолошке димензије. За придев трогательный, односно за његово значење које се у речнику Ожегова (2011) дефинише као вызывающий умиление, предлажемо следећу експликацију:

\section{Прилог 13}

Трогательный Х, трогательное обращение, трогательное письмо

\begin{tabular}{|c|c|}
\hline Током овог времена & Дуративни фрејм \\
\hline $\begin{array}{c}\text { Овај неко може да мисли } \\
\text { овако много пута: }\end{array}$ & Потенцијална мисао \\
\hline $\begin{array}{c}\text { „Неко је урадио нешто пре овог тре- } \\
\text { нутка, } \\
\text { Не као што то људи чине много пута. } \\
\text { Због тога знам да неко } \\
\text { други осећа нешто } \\
\text { веома добро према овоме некоме у } \\
\text { овом тренутк““ } \\
\text { Када овај неко мисли овако, } \\
\text { он/она не може да не осећа } \\
\text { нешто веома добро кратко време }\end{array}$ \\
\hline
\end{tabular}

Претходна експликација изражава пасивност у односу на експликације придева у српском језику очарајавући и неодољив у смислу одсуства димензије активације (субјекат само осећа емоцију, која га не покреће на неку активност), али она садржи елемент новине, док придев скучный не садржи димензију новине, али има потенцијал активације. Такође, придев трогательный садржи у свом значењу димензије валентности и потентности („Када овај неко мисли овако, он/она не може да не осећа нешто веома добро кратко време“). 


\section{Прилог 14}

Скучный Х, скучная программа, скучное видео

\begin{tabular}{|c|c|}
\hline Током овог времена & Дуративни фрејм \\
\hline $\begin{array}{c}\text { Овај неко може да мисли овако о } \\
\text { томе: }\end{array}$ & Потенцијална мисао \\
\hline $\begin{array}{c}\text { „“Ово је као много пута пре } \\
\text { Нећу да то буде овако } \\
\text { Хоћу да радим нешто друго сада““ }\end{array}$ & Мисао \\
\hline $\begin{array}{c}\text { Када овај неко мисли овако, } \\
\text { он/она може да осећа } \\
\text { нешто лоше због тога }\end{array}$ & Ocећање \\
\hline
\end{tabular}

Група придева у оквиру обрасца В2 прати сличну структуру, али има и једну додатну компоненту која указује на неку потенцијалну телесну реакцију (Goddard et al. 2019: 324). У датој групи придева понудићемо четири сценарија за следеће примере: сумъив, запањујући, напряженный и противный. За разлику од претходних придева, дате придеве нећемо међусобно упоређивати по фактору сличности јер се они доста разликују у домену своје семантике. За придев сумъив приказаћемо у виду експликације значење које је дефинисано у речнику Матице српске на следећи начин: онај који изазива сумњу, неповерење, подозрење у себе (због својих поступака, држања, карактера и сл.).

\section{Прилог 15}

Сумњив X, сумњива храна, сумњиво понашање

\begin{tabular}{|c|c|}
\hline $\begin{array}{c}\text { Током овог времена } \\
\text { (када се неке ствари дешавају некоме) }\end{array}$ & Дуративни фрејм \\
\hline Овај неко може да мисли овако много пута: & Потенцијална мисао \\
\hline „Нешто ће се & \\
после кратког времена & \\
Можда ће то бити веома добро & Мисао \\
за овог неког & \\
зажда ће бити веома лоше неког. & \\
Хоћу да знам шта ће се десити. & \\
Хоћу да знам сада. “ & \\
\hline
\end{tabular}




\begin{tabular}{|c|c|}
\hline $\begin{array}{c}\text { Када овај неко мисли овако, } \\
\text { он/она може да осећа нешто } \\
\text { што не осећају људи у многим другим тренуцима } \\
\text { Он/она може да осећа нешто лоше }\end{array}$ & Ocећање \\
\hline $\begin{array}{c}\text { У исто време нешто може да се деси у његовом/ } \\
\text { њеном телу због тога }\end{array}$ & Телесна реакција \\
\hline
\end{tabular}

У датој експликацији, као и код придева скучныгй, не постоји појачана потентност емоције која се осећа. Постоји компонента валентности („Он/она може да осећа нешто лоше“), као и компонента активације („Хоћу да знам шта ће се десити, хоћу да знам сада“). Елемент новине је изражен компонентом „Нешто ће се десити после кратког времена“.

Пошто је за овај образац, као и за образац В1, карактеристично присуство придева који имају глаголско порекло, навешћемо пример експликације за придев запањујући. За разлику од дефиниције речника Матице српске у којој се глагол запағити објашњава синонимичним изразима, типа јако се изненадити, запрепастити се, ми експлицирамо значење које указује на нешто што се дешава изненада, али што је неочекивано добро на следећи начин:

\section{Прилог 16}

запањујући X, запањујући изглед, запањујућа победа

\begin{tabular}{|c|c|}
\hline $\begin{array}{c}\text { Током овог времена } \\
\text { (када се неке ствари дешавају некоме) }\end{array}$ & Дуративни фрејм \\
\hline Овај неко може да мисли овако много пута: & Потенцијална мисао \\
\hline $\begin{array}{c}\text { „Ово нешто је веома добро, } \\
\text { Ја не знам како је могуће да је овакво. } \\
\text { Због тога ја не могу добро } \\
\text { да размишљам овог тренутка .“ }\end{array}$ & Мисао \\
\hline $\begin{array}{c}\text { Када овај неко мисли овако, } \\
\text { он/она не може да не осећа нешто добро због тога } \\
\text { Људи се не осећају овако много пута. }\end{array}$ & Осећање \\
\hline $\begin{array}{c}\text { У исто време он/она } \\
\text { може да осећа нешто } \\
\text { у његовом/њеном телу због тога. }\end{array}$ & Телесна реакција \\
\hline
\end{tabular}

Изложена експликација садржи три димензије која означавају простор емоција: валентност и потентност (,Када овај неко мисли овако, он/она не може да не 
осећа нешто добро због тога, Људи се не осећају овако много пута“), новину (дата емоција се појављује онда када дође до саме радње), док је овде нулта активација јер субјекат емоције није наведен да извршава никакву додатну активност.

Што се тиче придева напряженный, наша експликација ће се односити на значење које указује на несигуран положај или стање нечега (затруднительное, неуверенное, неспокойное положение, БТС, 1998):

\section{Прилог 17}

напряженный $X$, напряженное состояние, напряженные отношения

\begin{tabular}{|c|c|}
\hline $\begin{array}{c}\text { Током овог времена } \\
\text { (када се неке ствари дешавају некоме) }\end{array}$ & Дуративни фрејм \\
\hline Овај неко може да мисли овако много пута: & Потенцијална мисао \\
\hline $\begin{array}{c}\text { „Нешто веома лоше може } \\
\text { да се деси после кратког времена. } \\
\text { Не желим да се то деси. } \\
\text { Не могу да мислим о другим стварима сада .“ } \\
\text { У исто време, овај неко може да мисли } \\
\text { о овоме овако: } \\
\text { „Ја знам да ово није истина.“ }\end{array}$ & Мисао \\
\hline $\begin{array}{c}\text { Када овај неко мисли овако, } \\
\text { он/она може да осећа нешто лоше } \\
\text { због тога. } \\
\text { Не онако како се осећају људи } \\
\text { у многим другим тренуцима. }\end{array}$ & Oceћање \\
\hline $\begin{array}{c}\text { У исто време нешто може да се деси } \\
\text { у телу овог неког због тога. }\end{array}$ & Телесна реакција \\
\hline
\end{tabular}

За разлику од претходног српског придева запағујући, у датој експликацији су присутне све четири димензије емотивног простора: валентност и потентност („Када овај неко мисли овако, он/она може да осећа нешто лоше због тога. Не онако како се осећају људи у многим другим тренуцима“), новина (дата емоција се појављује онда када дође до саме радње односно ситуације изазивача емоције) и активација („Не желим да се то деси“).

Када говоримо о придеву противный, значење које ћемо објаснити кроз експликацију је у речнику Ожегова наведено као очень неприятный: 
Прилог 18

Противный X, противный запах, противный скрип

\begin{tabular}{|c|c|}
\hline $\begin{array}{c}\text { Током овог времена } \\
\text { (када се неке ствари дешавају некоме) }\end{array}$ & Дуративни фрејм \\
\hline Овај неко може да мисли овако много пута: & Потенцијална мисао \\
\hline $\begin{array}{c}\text { „Неко ради нешто веома лоше сада. } \\
\text { Нешто веома лоше се дешава } \\
\text { сада због тога““ }\end{array}$ & Мисао \\
\hline $\begin{array}{l}\text { Када овај неко мисли овако, } \\
\text { он/она не може да не осећа } \\
\text { нешто веома лоше због тога. }\end{array}$ & Осећање \\
\hline $\begin{array}{c}\text { У исто време он/она може } \\
\text { да осећа нешто лоше у телу као } \\
\text { када људи осећају нешто веома } \\
\text { лоше у устима }[\mathrm{m}] .5\end{array}$ & Телесна реакција \\
\hline
\end{tabular}

Три димензије су изражене у датој експликацији, укључујући валентност и потентност („Када овај неко мисли овако, он/она не може да не осећа нешто веома лоше због тога“), као и новину (дата емоција се појављује онда када дође до саме радње). Четврта димензија (активација) није присутна у наведеном значењу.

\section{5. Закључак}

У датом раду смо извршили лексичко-семантичку анализу дванаест придева са афективном и искуственом семантиком у српском и руском језику уз помоћ природног семантичког метајезика. Експликације датих двеју група придева су показале да се може направити дистинкција међу њима. Наиме, придеви са афективним значењем у својим експликацијама најчешће користе две димензије емотивног простора: валентност и потентност. Придеви са искуственим значењем осим димензија валентности и факултативно потентноси садрже у себи обично компоненту или активације или новине, или обе заједно. Будућа истраживања би могла да покажу како су четири психолошке димензије распоређене у оквиру значења придева са другачијом семантиком.

У закључку овог рада ћемо додати неколико речи и о значају овакве врсте семантичке анализе, као и о предностима који она пружа у односу на друге при-

5 Концепт уста представља семантички молекул у оквиру природног семантичког метајезика. Хипотеза која важи за семантичке молекуле јесте да могу бити изражени у свим језицима света, али да не представљају просте, односно недељиве концепте, као што су то семантички примитиви. 
ступе дефиницијама значења речи. Као што су читаоци рада имали прилике да запазе, у оквиру модела природног семантичког метајезика значења речи су дата у формату мини-текстова (експликација), који се састоји од лимитираног језика креираног на начин да се избегне циркуларност при дефинисању појмова ${ }^{6}$, уз принципе јасноће и доступности интуицији говорника језика. Овакав приступ аналитичару дозвољава да опише семантичку инваријацију прецизно, као и да детектује лексичку полисемију. Природни семантички метајезик такође поседује практичну апарутуру у виду прототипова експликација за реализацију семантичке анализе унутар различитих семантичких домена, као и различитих граматичких и синтаксичких облика у енглеском, али и у другим светским језицима7. Зачетник датог модела семантичке анализе, Ана Вјежбицка, сматра да било која запаженија теорија језика мора да се докаже и у домену лексикографије, те да треба створити практичне процедуре које би давале лексикографима упутство како да реше проблематична за њих питања, као што је то, на пример, област полисемије (видети Goddard 2017: 2). Такође, Ана Вјежбицка инсистира на томе да успешна семантичка анализа треба да доведе до високог степена прецизности у дефинисању значења, те због тога научница верује да лексикографија треба да усвоји одређене стандарде на начин на који је то уобичајено у области рачунарства, што подразумева креирање заједничког скупа термина и категорија који би се користили у дескрипцији значења. Тај скуп термина би представљао стандардизовани метајезик семантичке дескрипције, попут, на пример, природног семантичког метајезика, који би могао бити коришћен унутар истог или различитих језика.

Исто тако треба поменути да данас речници у свету представљају углавном електронске изворе, те су веома блиско повезани са облашћу процесирања природног језика и апликацијама за аутоматско превођење, сумаризацију и екстракција информација. Електронско процесирање језика у овом тренутку је подржано од стране великог броја лексичких база података и онтологија, које се међусобно не уклапају и имају мали степен стварне интероперабилности. Годард и Шели (Goddard and Schalley 2010) сматрају да би и област процесирања природног језика, као и област електронске лексикографије, имале велику корист уколико би репрезентације значења речи биле доступније интуицији говорника језика и уколико би биле транспарентније и ближе природном језику. Дакле, могућности коришћења природног семантичког језика су привлачне како за домен лексичке семантике, тако и за домене електронске и класичне лексикографије, али за домен рачунарства, посебно за област процесирања природног језика.

\footnotetext{
${ }^{6}$ На пример, придев сумњив се у Речнику српског језика (Вујанић и др. 2011) дефинише као „онај који изазива сумњу“, што представља типичан пример циркуларности у области лексикографије.

7 За сличне принципе наведенима се свакако залагао и представник Московске школе семантике Игор Мељчук у својој теорији смисао-текст, чији модел лексичке семантике је и можда најближи моделу природног семантичког метајезика Ане Вјежбице. Најновији развој дате теорије видети у монографији Мељчука (Mel’čuk, 2012).
} 


\section{Цитирана литература}

Большой толковый словарь русского языка (ред. Сергей Кузнецов). Первое издание, Санкт-Петербург: Норинт, 1998.

[Bol'shoĭ tolkovyĭ slovar' russkogo iâzyka (red. Serger Kuznetŝov). Pervoe izdanie: Sankt-Peterburg: Norint, 1998]

Драгићевић, Рајна. Придеви са значењем људских особина у савременом српском језику - творбена и семантичка анализа. књ. 18 изд. Београд: Институт за српски језик, Библиотека Јужнословенског филолога, 2001.

[Dragićević, Rajna. Pridevi sa značenjem ljudskih osobina u savremenom srpskom jeziku - tvorbena i semantička analiza. knj. 18. izd. Beograd: Institut za srpski jezik, Biblioteka Južnoslovenskog filologa, 2001]

Толковый словарь русского языка. Гл. ред. Ожегов Сергей, Шведова Наталия. Российская академия наук. Институт русского языка имени В.В. Виноградова. 3-е изд., доп. — Москва: Азбуковник, 1990.

[Tolkovyı̌ slovar' russkogo iāzyka (red. Ozhegov Sergeř, Shvedova Nataliia). Rossiǐskaiā akademiiā nauk. Institut russkogo iāzyka imeni V.V. Vinogradova. - 3-e izd., dop. — Москва.: Azbukovnik, 1990]

Речник српскога језика (ред. Милица Вујанић, Даринка Гортан-Премк, Милорад Дешић, Рајна Драгићевић, Мирослав Николић, Љиљана Ного, Васа Павковић, Никола Рамић, Рада Стијовић, Милица Радовић-Тешић, Егон Фекете). Нови Сад: Матица Српска, 2011.

[Rečnik srpskoga jezika (red. Milica Vujanić, Darinka Gortan-Premk, Milorad Dešić, Rajna Dragićević, Miroslav Nikolić, Ljiljana Nogo, Vasa Pavković, Nikola Ramić, Rada Stijović, Milica Radović-Tešić, Egon Fekete). Novi Sad: Matica Srpska, 2011]

Шаховский, Виктор. Лингвистическая теория эмоций. Москва: Гнозис, 2008.

[Šahovskij, Viktor. Lingvističeskaâ teoriâ èmocij. Moskva: Gnozis, 2008]

Davies, Mark. 2008. The Corpus of Contemporary American English: 450 million words, 1990-present. <http://corpus.byu.edu/coca $>$

Fontaine, Johnny, Klaus, Scherer, Cristina, Soriano (eds.) Components of emotional meaning: A sourcebook. Oxford: OUP, 2013.

Gillioz, Christelle, Johnny Fontaine, Cristina Soriano, Klaus Scherer. „Mapping Emotion Terms Into Affective Space“. Swiss Journal of Psychology 75 (3), 2016: 141-148.

Goddard, Cliff. „Interjections and emotions (with special reference to "surprise” and "disgust")“. Emotion Review 6(1), 2014: 53-63.

Goddard, Cliff." Natural Semantic Metalanguage and Lexicology". [In:] P. Hanks, G.M. de Schryver (eds.) International handbook of modern lexis and lexicography. Berlin: Springer, 2017, 1-15.

Goddard, Cliff, Maite Taboada, Radoslava Trnavac. "The semantics of evaluational adjectives: Perspectives from Natural Semantic Metalanguage and Appraisal". Functions of Language. 26(3), 2019: 308-342.

Goddard, Cliff, Anna Wierzbicka. Words and meanings: Lexical semantics across domains, languages, and cultures. Oxford: OUP, 2014.

Goddard, Cliff, Andrea Schalley. Semantic analysis. [In:] N. Indurkhya, F. J. Damerau (eds.) Handbook of natural language processing (2nd ed), Boca Raton, Florida: CRC Press/Taylor \& Francis, 2010, 92-120. 
Goddard, Cliff, Zhengdao Ye (eds.). "Happiness" and "pain” across languages and cultures. Amsterdam: John Benjamins, 2016 [First published 2014, as Special Issue of International Journal of Language and Culture, 1(2).]

Halliday, Michael, A.K. An Introduction to Functional Grammar (1st ed.). London: Edward Arnold, 1985.

Halliday, Michael, A. K. \& Christian M. I. M. Matthiessen. An introduction to Functional Grammar, 4th edn. London: Edward Arnold, 2014.

Harkins, Jean, Anna Wierzbicka (eds.). Emotions in cross-linguistic perspective. Berlin: Mouton, 2001.

Martin, Jim. Beyond exchange: Appraisal systems in English. [In:] S. Hunston, G. Thompson (eds.) Evaluation in text: Authorial stance andthe construction of discourse. Oxford: Oxford University Press, 2000, 142-175.

Martin, Jim." Evolving systemic functional linguistics: beyond the clause“. Functional Linguistics, 1(3), 2014: 1-24.

Martin, Jim, Peter White. The Language of Evaluation: Appraisal in English. Hampshier (UK) \& New York (USA): Palgrave Macmillan, 2005.

Mel'čuk, Igor. Semantics: From meaning to text. Amsterdam: John Benjamins, 2012.

Pang, Bo, Lillian Lee."Opinion Mining and Sentiment Analysis". Foundations and Trends in Information Retrieval 2(1-2), 2008: 1-135.

Picard, Rosemary W. Affective computing. Cambridge, MA: MIT Press, 1997.

Taboada, Maite. 2008. The SFU Review Corpus. Simon Fraser University, <http:// www.sfu.ca/ mtaboada/research/SFU_Review_Corpus.html $>$

Trnavac, Radoslava, Maite Taboada. How to be nice with words: Positive Appraisal in online news comments.

[In:] M. Kerry et al. (eds.) Studies in Ethnopragmatics, Cultural Semantics and Intercultural Communication: Ethnopragmatics and Semantic Analysis. Singapore: Springer Nature Singapore, 2019, 185-207.

White, Peter. „Attitudinal meanings, translational commensurability and linguistic relativity“. Revista Canaria de Estudios Ingleses, University of La Laguna, Canary Islands, 2012: 147-162.

Wierzbicka, Anna. Semantic primitives. Frankfurt: Athenaeum, 1972.

Wierzbicka, Anna. Emotions across languages and cultures. Cambridge: CUP, 1999.

Ye, Zhengdao (ed.). The Semantics of Nouns. Oxford: OUP, 2017.

Radoslava Trnavac

\section{SEMANTIC ANALYSIS OF A COUPLE OF ADJECTIVES WITH AFFECTIVE AND EXPERIENTIAL MEANINGS IN SERBIAN AND RUSSIAN}

\section{Summary}

In the paper by Goddard et al. (2019), we classified the meanings of adjectives into five groups. Here, we analyze the meanings of twelve adjectives with components of affect and experience based on the templates that are proposed in the above-mentioned work. A new theoretical point in this paper is that we distinguish between the two groups of adjectives based on the presence of four 
affective dimensions: valence, power, arousal and novelty (Fontaine et al. 2013). We argue that the adjectives with an affective component predominantly have the dimensions of valence and power, while the adjectives with experiential meaning have additional components either of novelty or arousal, or both.

Keywords: Natural Semantic Metalanguage, adjectives with affective and experiential meaning, dimensions of emotional space, Serbian, Russian. 